\title{
A call for better understanding the role of albumin in mediating VE-cadherin phosphorylation and endothelial barrier dysfunction in septic patients
}

\author{
Yupei $\mathrm{Li}^{1,2 \dagger}$, Luojia Jiang ${ }^{1 \dagger}$, Tao Song ${ }^{3}$, Yiran Wang ${ }^{3}$ and Baihai Su ${ }^{1,2,4^{*}}$ (D)
}

Letter to editor regarding "Endothelial damage in septic shock patients as evidenced by circulating syndecan-1, sphingosine-1-phosphate and soluble VE-cadherin: a substudy of ALBIOS" by Piotti et al. [1].

We read with great interest the article by Piotti et al. which showed that soluble VE-cadherin was independently associated with the need for renal replacement therapy during ICU stay and albumin supplementation lowered circulating VE-cadherin consistently over time, which might be partially attributed to an increase in intravascular volume as evidenced by higher NT-proBNP in septic patients receiving albumin supplementation [1]. While the authors briefly proposed the potential mechanisms underlying the endothelial protective effect of albumin (namely their anti-inflammatory and antioxidant properties), here we intend to add more discussion to fuel the understanding of the role of albumin in mediating VE-cadherin phosphorylation and endothelial barrier dysfunction in septic patients.

Cell-cell adherens junctions are regarded as the primary junctions in the peripheral microvasculature. VEcadherin, the main component of adherens junction, is

This comment refers to the article available online at https://doi.org/10.1186/ s13054-021-03545-1.

*Correspondence: subaihai@scu.edu.cn

${ }^{\dagger}$ Yupei Li and Luojia Jiang have contributed equally to this work.

${ }^{1}$ Department of Nephrology, Med-X Center for Manufacturing, West

China Hospital, Sichuan University, Guoxue Alley No. 37, Chengdu 610041,

Sichuan Province, China

Full list of author information is available at the end of the article anchored to the actin cytoskeleton through catenins $(\alpha-$, $\beta-, \gamma^{-}$, and p120-catenin) and participate in the regulation of endothelial barrier integrity and permeability [2]. In sepsis, inflammatory mediators (namely lipopolysaccharide, cytokines, thrombin, and complement 5 a etc.) could not only down-regulate the expression of VE-cadherin on the membrane of endothelial cells, but also impair the cytoskeleton-junction response characterized by myosin light chain phosphorylation and tyrosine phosphorylation of VE-cadherin through the activation of Src family kinases, which significantly contributes to adherens junction dissociation [3]. Meegan and colleagues further identified citrullinated histone 3 as a functional contributor to cell-cell adherens junction opening and cytoskeleton reorganization, causing microvascular endothelial barrier dysfunction [4]. Since a previous publication has suggested the remarkable histone-neutralization effect of albumin characterized by decreased histone-induced endothelial cell damage [5], we speculate that albumin might also alleviate the impaired cell-cell adherens junctions and endothelial barrier function possibly by antagonizing histone-mediated adherens junction loss and cytoskeleton reorganization. Of note, this protective effect of albumin might be independent of the expression of VE-cadherin on the surface of endothelial cells. Future explorations are thus encouraged to clarify the mechanisms underlying the effect of albumin supplementation in mediating tyrosine phosphorylation of VE-cadherin, preventing endothelial barrier dysfunction and improving survival in patients with sepsis. original author(s) and the source, provide a link to the Creative Commons licence, and indicate if changes were made. The images or other third party material in this article are included in the article's Creative Commons licence, unless indicated otherwise in a credit line to the material. If material is not included in the article's Creative Commons licence and your intended use is not permitted by statutory regulation or exceeds the permitted use, you will need to obtain permission directly from the copyright holder. To view a copy of this licence, visit http://creativecommons.org/licenses/by/4.0/. The Creative Commons Public Domain Dedication waiver (http://creativeco mmons.org/publicdomain/zero/1.0/) applies to the data made available in this article, unless otherwise stated in a credit line to the data. 


\section{Authors' response}

\author{
Pietro Caironi ${ }^{5}$, Jennifer Marie Theresia Anna Meessen ${ }^{6}$, \\ Arianna Piotti ${ }^{7}$ and Roberto Latini ${ }^{6}$. \\ ${ }^{5}$ Department of Anesthesia and Critical Care, AOU S. Luigi Gonzaga, \\ Orbassano and Department of Oncology, University of Turin, Turin, Italy \\ ${ }^{6}$ Department of Cardiovascular Medicine, Institute for Pharmacological \\ Research Mario Negri IRCCS, Milan, Italy \\ ${ }^{7}$ Department of Biochemistry and Molecular Pharmacology, Mario Negri \\ Institute for Pharmacological Research IRCCS, Milan, Italy
}

\section{To the editor}

We read with interest the letter by Yupei Li and colleagues, discussing a potential novel mechanism by which albumin might counteract the altered endothelial permeability characterizing patients with sepsis. In support to the histone-neutralizing effect of albumin, in cultured endothelial cells, we reported that higher PTX3 at day 1 was associated with greater hemodynamic instability, suggesting increase in PTX3 secretion as a compensatory response. Similarly, in patients receiving albumin supplementation, PTX3 appeared significantly lower than in patients receiving crystalloids [6]. In another in-vitro study, Otero $\mathrm{K}$ and colleagues reported that advancedglycation end-product-modified bovine serum albumin (BSA), an abnormal form of albumin, induces endothelial dysfunction and increased permeability through VEcadherin complex disruption, as observed in diabetes or aging, an effect not observed with normal BSA [7]. Taken together, these findings suggest that albumin, when normally functioning, may preserve endothelial permeability also by maintaining the integrity of VE-cadherin complex.

Despite these interesting speculations, the overall picture of the role of albumin in relation to endothelial permeability is likely more complex. Very often, hypoalbuminemia, during septic shock, is considered per se a proof of increased endothelial permeability, although this statement remains unproven. Indeed, during sepsis, hypoalbuminemia is a common finding often associated with an increased risk of death, but several data have shown that during systemic inflammation albumin transcapillary escape rate may not be different from that of healthy subjects [8]. Moreover, even the association between glycocalyx disruption, as denoted by elevated levels of syndecan-1, and endothelial permeability has been challenged [9]. Finally, volume expansion with $20 \%$ albumin as observed in clinical conditions characterized by increased endothelial permeability, such as in patients with burns, appeared similar to that observed in normal conditions [10].

Independent of the mechanisms potentially involved, albumin supplementation targeting the restoration of its normal serum concentration appears a reasonable approach during sepsis. When compared to a fluid strategy including only crystalloids, in the ALBIOS trial, albumin replacement appeared associated with a faster normalization of cardiovascular dysfunction, as well as with a reduced net positive fluid balance during the resuscitation phase. Whether or not these advantages are related to ancillary functions of albumin (in addition to its primary oncotic property) remains unproven. We are currently conducting a novel multicenter randomized controlled trial, the ALBumin Italian Outcome Septic Shock-BALANCED (ALBIOSS-BALANCED) trial (\#NCT03654001), comparing, in patients with septic shock, albumin replacement in addition to crystalloids to the use of only crystalloids over the first 90 days of treatment. Already 400 patients have been enrolled and we do hope that the results of such a trial, together with the ARISS trial (Albumin Replacement Therapy in Septic Shock, \#NCT03869385) ongoing in Germany, will definitely prove whether albumin supplementation in septic shock improves survival.

\section{Acknowledgements \\ Not applicable.}

\section{Authors' contributions}

LYP and SBH conceived of the concept and planned the content. LYP and J J wrote the first draft. SBH reviewed and revised the manuscript. All authors read and approved the final manuscript.

\section{Funding}

This work was financially sponsored by the Science and Technology Achievement Transformation Fund of West China Hospital of Sichuan University (Grant No. CGZH19006).

Availability of data and materials

Not applicable.

\section{Declarations}

Ethics approval and consent to participate

Not applicable.

\section{Consent for publication}

Not applicable.

\section{Competing interests}

The authors declare that they have no competing interests.

\section{Author details}

1Department of Nephrology, Med-X Center for Manufacturing, West China Hospital, Sichuan University, Guoxue Alley No. 37, Chengdu 610041, Sichuan Province, China. ${ }^{2}$ Institute for Disaster Management and Reconstruction, Sichuan University, Chengdu 610207, Sichuan Province, China. ${ }^{3}$ College of Polymer Science and Engineering, Sichuan University, Chengdu 610065, Sichuan Province, China. ${ }^{4}$ The First People's Hospital of Shuangliu District, Chengdu 610200, Sichuan Province, China. ${ }^{5}$ Department of Anesthesia and Critical Care, AOU S. Luigi Gonzaga, Orbassano and Department of Oncology, University of Turin, Turin, Italy. ${ }^{6}$ Department of Cardiovascular Medicine, Institute for Pharmacological Research Mario Negri IRCCS, Milan, Italy. ${ }^{7}$ Department of Biochemistry and Molecular Pharmacology, Mario Negri Institute for Pharmacological Research IRCCS, Milan, Italy. 
Received: 24 March 2021 Accepted: 24 May 2021

Published online: 01 July 2021

\section{References}

1. Piotti A, Novelli D, Meessen JMTA, Ferlicca D, Coppolecchia S, Marino A, et al. Endothelial damage in septic shock patients as evidenced by circulating syndecan-1, sphingosine-1-phosphate and soluble VE-cadherin: a substudy of ALBIOS. Crit Care. 2021;25:113. https://doi.org/10.1186/ s13054-021-03545-1

2. Ma Y, Yang X, Chatterjee V, Meegan JE, Beard RS Jr, Yuan SY. Role of neutrophil extracellular traps and vesicles in regulating vascular endothelial permeability. Front Immunol. 2019;10:1037.

3. Gong P, Angelini DJ, Yang S, Xia G, Cross AS, Mann D, et al. TLR4 signaling is coupled to SRC family kinase activation, tyrosine phosphorylation of zonula adherens proteins, and opening of the paracellular pathway in human lung microvascular endothelia. J Biol Chem. 2008;283:13437-49.

4. Meegan JE, Yang XY, Beard RS, Jannaway M, Chatterjee V, Taylor-Clark $T E$, et al. Citrullinated histone 3 causes endothelial barrier dysfunction. Biochem Biophys Res Commun. 2018;503:1498-502.

5. Iba T, Hamakubo T, Nagaoka I, Sato K, Thachil J. Physiological levels of pentraxin 3 and albumin attenuate vascular endothelial cell damage induced by histone H3 in vitro. Microcirculation. 2016;23:240-7.
6. Caironi P, Masson S, Mauri T, Bottazzi B, Leone R, Magnoli M, Barlera S, Mamprin F, Fedele A, Mantovani A, Tognoni G, Pesenti A, Gattinoni L, Latini R, ALBIOS Biomarkers Study Investigators. Pentraxin 3 in patients with severe sepsis or shock: the ALBIOS trial. Eur J Clin Investig. 2017;47:73-83.

7. Otero K, Martinez F, Beltran A, Gonzalez D, Herrera B, Quintero G, Delgado $\mathrm{R}$, Rojas A. Albumin-derived advanced glycation end-products trigger the disruption of the vascular endothelial complex in cultured human and murine endothelial cells. Biochem J. 2001;359:567-74.

8. Komaromi A, Estenberg U, Hammarqvist F, Rooyackers O, Wernerman J, Norberg A. Simultaneous assessment of the synthesis rate and transcapillary escape rate of albumin in inflammation and surgery. Crit Care. 2016;20:370.

9. Hahn RG, Zdolsek M, Krizhanovskii C, Ntika S, Zdolsek JH. Elevated plasma concentrations of syndecan-1 do not correlate with increased capillary leakage of 20\% albumin. Anesth Analg. 2020;132:856-65.

10. Zdolsek M, Hahn RG, Sjöberg F, Zdolsek JH. Plasma volume expansion and capillary leakage of $20 \%$ albumin in burned patients and volunteers. Crit Care. 2020;24:191.

\section{Publisher's Note}

Springer Nature remains neutral with regard to jurisdictional claims in published maps and institutional affiliations.
Ready to submit your research? Choose BMC and benefit from:

- fast, convenient online submission

- thorough peer review by experienced researchers in your field

- rapid publication on acceptance

- support for research data, including large and complex data types

- gold Open Access which fosters wider collaboration and increased citations

- maximum visibility for your research: over 100M website views per year

At BMC, research is always in progress.

Learn more biomedcentral.com/submissions 